\title{
Proximate analysis and mineral content of three commonly used seasonings in Nigeria
}

\author{
Umedum Ngozi Lillian ${ }^{1}$, Udeozo Ifeoma Prisca ${ }^{2}$, Muoneme Ozioma ${ }^{1}$, \\ Okoye Nkechi ${ }^{1}$, Iloamaeke Ifeoma ${ }^{1}$ \\ ${ }^{1}$ (Department of Pure and Industrial Chemistry/ Nnamdi Azikiwe University, Awka, Nigeria) \\ ${ }^{2}$ (Department of Chemical Sciences /Tansian University, Oba, Nigeria)
}

\begin{abstract}
Three common brands of seasonings labeled $X, Y, Z$ were analyzed for proximate, monosodium glutamate (MSG), and mineral composition. The moisture content of the samples was found to range between 0.99 and $3.01 \%$. Crude protein, crude fat and ash contents were : $9.18-12.87 ; 2.50-3.50$ and $54.00-75.00 \%$ dry matter (DM) respectively. MSG content ranged between 0.34 and $0.67 \%$. The concentrations of some metals$\operatorname{copper}(\mathrm{Cu})$, zinc $(\mathrm{Zn})$, cadmium $(\mathrm{Cd})$, and lead $(\mathrm{Pb})$ were determined using Atomic Absorption Spectroscopy and the results revealed that some of these metals were present in some brands but absent in others.
\end{abstract}

Keywords - Minerals, Monosodium Glutamate (MSG), Nigeria, Proximate Analysis, Seasonings

\section{Introduction}

Seasonings are ingredients which are added to foods to enhance their flavor. These ingredients include salt; herbs such as mint, thyme; spices such as chili powder; condiments such as mustard; vinegar. Apart from adding flavor to foods, some seasonings also contain medical and health benefits [1]. Some of these benefits have been extensively studied while the potential of many are yet to be explored. Garlic, for instance, contains antioxidants, which help protect cells from damage caused by free radicals and also help to inhibit the development of tumor cells. Studies have shown that persons who consumed more garlic in their diets had lower incidence rates of certain cancers, especially colon and stomach cancers [1]. It contains beneficial phytochemicals such as polyphenols and sulphides [2]. The large quantities of sulphides present in garlic especially the bulb are antimicrobial and anti-inflammatory and therefore help to prevent or fight infectious diseases; It has also been proven that they lower the levels of "bad" cholesterol and triglycerides in the blood. The implication is that garlic may help prevent atherosclerosis and therefore cardiovascular disorders like blood clots, strokes and heart attacks. Ginger is known for its antibiotic, anti-inflammatory, anti-clotting, antidiarrheal, anti-cancer and anti-depressant activities. It has been used as a decongestant and its consumption has led to reduction in "bad" cholesterol [3]. Thyme is an expectorant and has antiseptic actions; lowers cholesterol levels; and eliminates scalp itching and flaking caused by candidiasis [4]. Turmeric eases stomach acid, prevents blood clotting, arrests poisonous toxins before they get to the liver, lowers blood sugar and cholesterol. It is also being studied for its potential cancer-fighting and anti-inflammatory properties [5]. Cayenne pepper acts as a catalyst for other herbs. It has antibacterial and antioxidant actions; it helps to ward off colds, sinus infections, and sore throats. Cayenne pepper helps to relieve arthritis and back pain. It burns calories since hot peppers in foods speed up metabolism [4], [5]. Other common examples of seasonings include cinnamon, curry, onion, cinnamon, rosemary, parsley and sesame seeds. As food, seasonings have been shown to be sources of nutrients [6], [7], [8], [9]. Wide variations in concentrations of trace metals have been reported in seasonings [9], [10], [11]. Heavy metal contamination in the food chain is caused by environmental pollution and lead $(\mathrm{Pb})$ and copper $(\mathrm{Cu})$ have aroused considerable concern [12].In Nigeria seasonings are manufactured as bouillon cubes and other well packaged powdery forms with different brand names. They contain salt, monosodium glutamate (MSG), and some spices as indicated by the manufacturers and are used extensively in food preparation in most homes and restaurants [7], [9], [13].

MSG is the sodium salt of the amino acid glutamic acid and has long been recognized as a flavor enhancer. It is sold as a fine white crystalline substance similar in appearance to salt or sugar. It is considered a primary taste, umami. Pure MSG does not have a pleasant taste until it is combined with a consonant savory smell [14]. Glutamate is found in most foods especially foods that are high in protein such as meat, fish, and dairy products. Other sources include mushrooms and tomatoes. Glutamate is said to cause a tingling feeling and a marked persistency of taste sensation such that it provides a feeling of satisfaction. It improves the flavor of many food products and is therefore widely used in processed foods [15]. However, recently, there have been speculations in this part of the world that these manufactured seasonings are directly or indirectly responsible for the prevalence of some ailments or diseases which are the major causes of morbidity in Nigeria. Some of these diseases are cardiovascular diseases, cancer, diabetes and osteoporosis. This study was carried out to 
identify the proximate composition, MSG content and mineral composition of the seasonings readily consumed in Nigeria. Two toxic metals $(\mathrm{Pb}$ and $\mathrm{Cd})$ and two essential micronutrients $(\mathrm{Cu}$ and $\mathrm{Zn})$ were determined to assess human ingestion of these metals from the consumption of foods prepared with these seasonings.

\subsection{Sample Source and Preparation}

\section{Materials and Methods}

Three different brands of seasonings were purchased from Eke-Awka Market in Awka, Southern Nigeria. They were ground into powder using a food blender and transferred into polythene bags labeled X, Y, and $\mathrm{Z}$. The bags were stored in a dessicator containing calcium chloride to avoid absorption of moisture.

\subsection{Proximate Analysis}

Proximate analyses for moisture, crude fat, crude protein, and ash were carried out in accordance with the official methods of the Association of Official Analytical Chemists (AOAC) [16]. Total carbohydrates were estimated by difference: 100 - (\% moisture $+\%$ crude protein $+\%$ crude fat $+\%$ ash content).

\subsection{Determination of MSG content}

This was done by titrimetry. $0.5 \mathrm{~g}$ of each sample was dissolved in $20 \mathrm{ml}$ of distilled water and four drops of bromothymol blue indicator solution were added. This was titrated with $0.1 \mathrm{M}$ sodium hydroxide $(\mathrm{NaOH})$ to a blue end point and the titer value, $\mathrm{V}$ was recorded. The percentage MSG was calculated thus:

$\% \mathrm{MSG}=\%$ glutamic acid $\times 1.15$

$\%$ glutamic acid $=(\mathrm{V} \times 14.71 \times 100) /($ weight of sample $\times 1000)$

Where $1 \mathrm{ml}$ of $0.1 \mathrm{M} \mathrm{NaOH}=14.71 \mathrm{mg}$ of glutamic acid and 1.15 is factor of MSG. $\mathrm{V}$ is titer value of sample in $\mathrm{ml}$

\subsection{Determination of mineral content}

$1 \mathrm{~g}$ of sample was digested with $20 \mathrm{ml}$ of $2: 1 \mathrm{HNO}_{3} / \mathrm{HClO}_{4}$ and heated until white fumes were evolved. The digested samples were then filtered into standard $50 \mathrm{ml}$ volumetric flask and made up to the mark with distilled water. The minerals copper $(\mathrm{Cu})$, zinc $(\mathrm{Zn})$, cadmium $(\mathrm{Cd})$, and lead $(\mathrm{Pb})$ were determined using air acetylene flame atomic absorption spectrometry (BUCK Scientific, Model 200A). Glassware used for analyses were thoroughly cleaned and all reagents used were of analytical grade.

\section{Results and Discussion}

The results obtained from proximate analysis of the seasonings are shown in TABLE 1. Moisture was low ranging in value between $0.99 \%$ and $3.01 \%$. This is an indication that their shelf-life is elongated and deterioration in quality due to microbial activity may be limited. The crude protein content of the seasonings ranged between $9.18 \%$ and $12.87 \%$. Sample $\mathrm{Y}$ had the highest value $(12.87 \%)$ while $\mathrm{Z}$ had the lowest $(9.18 \%)$. These values are comparable to those reported for spices such as Monodora myristica and Tetrapleura tetraptera [17], but lower than those reported for bouillon cubes [9]. The crude fat ranged between $2.5 \%$ and $3.5 \%$. Y had the highest crude fat content (3.5\%) and $\mathrm{Z}$ had the lowest (2.5\%). These values were comparable to values reported for traditional spice Tetrapleura tetraptera [17] and Scorodophleus zenkeri fruit, a wild plant used as spice [6], but lower than those reported for bouillon cubes[9]. The ash content ranged between $54.00 \%$ and $75.00 \%$; $\mathrm{X}$ had the highest value while $\mathrm{Y}$ had the lowest. These values were high. High ash content is an indication of high inorganic mineral content [18]. The carbohydrate content ranged between $7.40 \%$ and $28.64 \%$. $\mathrm{Y}$ had the highest value $(28.64 \%)$ while $\mathrm{X}$ had the lowest value $(7.40 \%)$. The values of $\mathrm{Y}$ and $\mathrm{Z}$ were comparable to the values reported for bouillon cubes [9] and Monodora myristica[17]. However they were low compared with values reported for some spices [7], [17]. The low carbohydrate content of the three brands of seasonings is an indication of their low calorie content.

The values for the MSG content as shown in TABLE 1 also ranged between $0.34 \%$ and $0.67 \%$. X had the highest MSG content $(0.67 \%)$ and $\mathrm{Y}$ had the lowest $(0.34 \%)$.

TABLE 1: Proximate Composition and MSG content of Three Brands of Seasonings in Nigeria (\%)

\begin{tabular}{ccccccc}
\hline Sample & Moisture & Protein & Fat & Ash & Carbohydrate & MSG \\
\hline X & 3.01 & 11.59 & 3.00 & 75.00 & 7.40 & 0.67 \\
Y & 0.99 & 12.87 & 3.50 & 54.00 & 28.64 & 0.34 \\
Z & 1.49 & 9.18 & 2.50 & 69.00 & 17.83 & 0.65 \\
\hline
\end{tabular}


TABLE 2: Copper, Zinc, Lead, and Cadmium levels in the seasonings ( $\mathrm{mg} / \mathrm{Kg})$

\begin{tabular}{ccccc}
\hline Sample & $\mathrm{Cu}$ & $\mathrm{Zn}$ & $\mathrm{Pb}$ & $\mathrm{Cd}$ \\
\hline $\mathrm{X}$ & 2.57 & $\mathrm{NP}$ & 0.10 & 0.14 \\
$\mathrm{Y}$ & $\mathrm{NP}$ & 0.12 & 0.16 & 0.07 \\
$\mathrm{Z}$ & 0.42 & 0.04 & 0.10 & 0.16 \\
\hline
\end{tabular}

$\mathrm{NP}=$ not present

MSG's use has become controversial and questions have been raised since the early 1980s about its safety [19]. The safety of MSG has been studied worldwide. Regulatory authorities like The Joint Food and Agriculture Organization of the United Nations/ World Health Organization Expert Committee on Food Additives (JECFA) and the Federation of American Societies for Experimental Biology have conducted evaluations on its use. Many countries have regulatory agencies that are responsible for monitoring foods and drugs consumed by its citizens. India's Prevention of Food Adulteration Act sets in upper limit of $1 \% \mathrm{MSG}$ in food because MSG has been associated with nausea, headaches, burning sensation, and facial pressure and chest pains in some individuals who exhibit an allergic-type reaction or hypersensitivity on consumption of MSG. Retardation and birth defect in offspring among pregnant women has also been reported [19]. Based on this limit, the results obtained for the seasonings were below the upper limit. $\mathrm{X}$ and $\mathrm{Z}$ had relatively high values of MSG when compared to Y. However, it is recommended that those who suffer from this sensitivity avoid the use of MSG.

The mineral analysis revealed the presence of the essential metals like copper $(\mathrm{Cu})$ and zinc $(\mathrm{Zn})$ in some samples as shown in TABLE 2. For $\mathrm{Cu}$, the concentration in $\mathrm{X}$ was $2.57 \mathrm{mg} / \mathrm{Kg}$ while $\mathrm{Z}$ was $0.42 \mathrm{mg} / \mathrm{Kg}$. Copper was absent in Y. These values were below the WHO limit for $\mathrm{Cu}(50 \mathrm{mg} / \mathrm{Kg})$. This is acceptable because $\mathrm{Cu}$ plays an important role in a wide range of physiological processes in the body which include iron utilization, elimination of free radicals, development of bone and connective tissue and production of the skin and hair pigment called melanin. For $\mathrm{Zn}, \mathrm{Y}$ and $\mathrm{Z}$ had concentrations of 0.12 and $0.04 \mathrm{mg} / \mathrm{Kg}$ respectively. $\mathrm{Zn}$ was not present in X. These values were very well below the WHO limit in spices for $\mathrm{Zn}(100 \mathrm{mg} / \mathrm{Kg})$. Zinc plays a vital role in growth and has a recognized action on more than 300 enzymes by participating in their structure or their catalytic and regulatory action [20]. It helps maintain a healthy immune system and supports normal growth and development during pregnancy, childhood and adolescence. It helps in sperm development and is needed for ovulation and fertilization. Zinc deficiency results in growth retardation, hair loss, diarrhea, delayed sexual maturation and impotence, eye and skin lesions, and loss of appetite. Its deficiency may also affect bone metabolism. Even though these two metals are essential, very high concentrations of them could be more deleterious than nutritious.

The concentrations of the heavy metals as shown in TABLE 2 ranged between $0.00 \mathrm{mg} / \mathrm{Kg}$ and $0.10 \mathrm{mg} / \mathrm{Kg}$ for lead $(\mathrm{Pb})$ and $0.07 \mathrm{mg} / \mathrm{Kg}$ and $0.16 \mathrm{mg} / \mathrm{Kg}$ for cadmium $(\mathrm{Cd})$.

The presence of $\mathrm{Pb}$ in foods may be the result of environmental contamination, pick up of metal from equipment, or the solder of tin cans. The target organs for lead poisoning are the $b$ ones, brain, blood, kidneys, and the thyroid glands. Thus lead exposure has been reported to cause severe anemia, permanent brain damage, neurological disorders, reproductive problems, diminished intelligence and many other diseases [20].

Cadmium gets into the environment during zinc mining. Other sources include insecticides, fungicides, commercial fertilizers, dental alloys, motor oils, and exhaust. Cd is ingested by humans mainly through food. At elevated levels, Cd has been shown to cause kidney problems, anemia, hypertension and possibly cancer [21]

\section{Conclusion}

The present study has shown that the seasonings contain moderate amounts of fat, protein and carbohydrate which are nutrients needed by the body. The ash contents suggest that they are good sources of minerals. However, the presence of the toxic metals, lead and cadmium in some of the seasonings is an issue of great concern since these metals can be toxic even at very low concentrations. Though the MSG content is low, it is advised that individuals, who have some sort of allergy on consumption of MSG, should not use the seasonings.

\section{References}

[1] J.Herndon,Medical benefits of food seasonings, http://www.livestrong.com/article/340034-medical-benefits-of-food-seasonings/ 2010 , accessed 14/6/2013.

[2] K.Scott,Medical seasonings-the health benefits in herbs and spices; the medical benefits of garlic, Clinical Medicine Journal, 2012, http://www.ClassicalMedicineJournal.com/the-classical-medicine-journal/tag/benefits-of-seasonings , accessed 22/6/2013

[3] O.B Ajayi, S.F Akomolafe and F.T Akinyemi, Food value of two varieties of ginger commonly consumed in Nigeria, ISRN Nutrition,2013(2013), http://dx.doi.org/10.5402/2013/359727.

[4] E.Lingenfelter, The health benefits and uses of 14 herbs, seasonings and spices, 2011, http://www.articlesbase.com/supplementsand-vitamins-articles/the-health-benefits-uses-of-14hrerbs-seasonings-spices-5405335.html, accessed 28/6/2013 
[5] G.Aukerman, Wexner Medical Center, The Ohio State http://medicalcenter.osu.edu/mediaroom/releases/pages/Seasonal-Seasonings-Can-Have-Surprising-Health-Benefits.aspx , accessed $22 / 6 / 2013$

[6] A.A Bouba, N.Y Njintang, H.S Foyet, J.Scher, D.Montet and C.M.F Mbofung, Proximate composition, mineral and vitamin content of some wild plants used as spices in Cameroon, Food and Nutrition Sciences, (3),2012, 423-432

[7] G.A Otunola, O.B Oloyede, A.T Oladiji and A.J Afolayan, Comparative analysis of the chemical composition of three spicesAllium sativum, L.zingiber officinale rocs and Capsicum frutescens L commonly consumed in Nigeria, African Journal of Biotechnology, 9(41), 2010,6927-6931

[8] C.U Ogunka-Nnoka and H.D Mepba, Proximate composition and antinutrient contents of some common spices in Nigeria, The Open Food Science Journal, (2), 2008, 62-67

[9] E.O Akpanyung, Proximate and mineral element composition of bouillon cubes produced in Nigeria, Pakistan Journal of Nutrition, 4(5), 2005, 327-329

[10] E.C Garcia, C.Cabrera, M.L Lorenzo and M.C Lopez, Chromium levels in spices and aromatic herbs, The Sci. Total Environ, 247, 2000, 51-56

[11] T.M Ansari, M. Ikram, M. Najam-ul-Haq, O. Fayyaz, I. Ghafoor and N. Khalid, Essential trace metal (Zn, Mn, Cu and Fe) levels in plants of medicinal importance, J. Biol. Sc, 4, 95-99

[12] I.C Nnorom, O. Osibanjo and K. Ogugua, Trace heavy metal levels of some bouillon cubes and food condiments readily consumed in Nigeria, Pakistan Journal of Nutrition, 6(2), 2007, 122-127

[13] N.M Nwinuka, G.O Ibeh and G.L Ekeke, Proximate composition and levels of some toxicants in four commonly consumed spices, Journal of Applied Science, Environmental Management, 9(1), 2005, 150-155

[14] E.T Rolls, Functional neuroimaging of umami taste; what makes umami pleasant, The American Journal of Clinical Nutrition, 90(3), 2009, 804-813

[15] J.M deMan, Principles of food chemistry (Van Nostrand Reinhold: New York, 1990)

[16] AOAC. Official Methods of Analysis.Association of Official Analytical Chemists, $16^{\text {th }}$ ed., Washington DC, 1995

[17] E.N Agomuo, E.N Onyeike and E.O Anosike, Proximate composition and fatty acid profile of Monodora myristica(ehuru)and Tetrapleura tetraptera(uhiokirihio), International Research Journal, ISSN:2006-1730, 2011

[18] O.I Oloyede, Chemical profile of unripe pulp of Carica papaya, Pakistan Journal of Nutrition, 4(6), 2005, 379-381

[19] A.K Basu, P.Chattopadhyay, U.Roychudhuri and R. Chakraborty, Development of biosensor based on immobilized L-glutamate oxidase for determination of monosodium glutamate in food, Indian Journal of Experimental Biology, 44, 2006, 392-398

[20] M.A Nkansah and C.O Amoako , Heavy metal content of some common spices available in market in the Kumasi Metropolis of Ghana, American Journal of Scientific and Industrial Research, 1(2), 2010, 158-163

[21] N.L Umedum and P.A.C Okoye, Comparative study of carbonized, uncarbonized; activated and unactivated sawdust and rice husk for sequestration of lead and cadmium ions from aqueous solution, ANACHEM Journal, 5(1), 2011, 1052-1058 